\title{
Synergistic inhibition of human cytomegalovirus replication by interferon-alpha/beta and interferon-gamma Bruno Sainz Jr ${ }^{\dagger}$, Heather L LaMarca ${ }^{\dagger}$, Robert F Garry and Cindy A Morris*
}

\author{
Address: Department of Microbiology and Immunology, Program in Molecular Pathogenesis and Immunity, Tulane University Health Sciences \\ Center, 1430 Tulane Avenue, SL-38, New Orleans, LA, 70112, USA \\ Email: Bruno Sainz - bsainz@scripps.edu; Heather L LaMarca - hlamarc@tulane.edu; Robert F Garry - rfgarry@tulane.edu; \\ Cindy A Morris* - cmorris2@tulane.edu \\ * Corresponding author †Equal contributors
}

Published: 23 February 2005

Virology Journal 2005, 2:14 doi:10.1186/1743-422X-2-14

This article is available from: http://www.virologyj.com/content/2/I//4

(C) 2005 Sainz et al; licensee BioMed Central Ltd.

This is an Open Access article distributed under the terms of the Creative Commons Attribution License (http://creativecommons.org/licenses/by/2.0), which permits unrestricted use, distribution, and reproduction in any medium, provided the original work is properly cited.
Received: 17 February 2005

Accepted: 23 February 2005

\begin{abstract}
Background: Recent studies have shown that gamma interferon (IFN- $\gamma$ ) synergizes with the innate IFNs (IFN- $\alpha$ and IFN- $\beta$ ) to inhibit herpes simplex virus type I (HSV-I) replication in vitro. To determine whether this phenomenon is shared by other herpesviruses, we investigated the effects of IFNs on human cytomegalovirus (HCMV) replication.

Results: We have found that as with HSV-I, IFN- $\gamma$ synergizes with the innate IFNs (IFN- $\alpha / \beta)$ to potently inhibit HCMV replication in vitro. While pre-treatment of human foreskin fibroblasts (HFFs) with IFN- $\alpha$, IFN- $\beta$ or IFN- $\gamma$ alone inhibited HCMV plaque formation by $\sim 30$ to 40 -fold, treatment with IFN- $\alpha$ and IFN- $\gamma$ or IFN- $\beta$ and IFN- $\gamma$ inhibited HCMV plaque formation by I63- and 662-fold, respectively. The generation of isobole plots verified that the observed inhibition of $\mathrm{HCMV}$ plaque formation and replication in HFFs by IFN- $\alpha / \beta$ and IFN- $\gamma$ was a synergistic interaction. Additionally, real-time PCR analyses of the HCMV immediate early (IE) genes (IEI and IE2) revealed that IE mRNA expression was profoundly decreased in cells stimulated with IFN- $\alpha / \beta$ and IFN- $\gamma$ ( $\sim 5$ - I I-fold) as compared to vehicle-treated cells. Furthermore, decreased IE mRNA expression was accompanied by a decrease in IE protein expression, as demonstrated by western blotting and immunofluorescence.
\end{abstract}

Conclusion: These findings suggest that IFN- $\alpha / \beta$ and IFN- $\gamma$ synergistically inhibit HCMV replication through a mechanism that may involve the regulation of IE gene expression. We hypothesize that IFN- $\gamma$ produced by activated cells of the adaptive immune response may potentially synergize with endogenous type I IFNs to inhibit HCMV dissemination in vivo.

\section{Background}

Human cytomegalovirus (HCMV) is a ubiquitous betaherpesvirus that affects $60-80 \%$ of the human population [1]. The lytic replication cycle of HCMV is a temporally regulated cascade of events that is initiated when the virus binds to host cell receptors. Upon entry into the cell, the viral DNA translocates to the nucleus, where expression of viral immediate early (IE), early and late genes occurs in a stepwise fashion [2]. While generally asymptomatic in immunocompetent individuals, primary HCMV infection may cause infectious mononucleosis and has been associated with atherosclerosis and coronary restenosis [3,4]. Furthermore, HCMV is the leading contributor of congenital viral infections in the United States and Europe, 
causing cytomegalic inclusion disease, pneumonia and severe neurological anomalies in infected neonates [5-7].

Like other herpesviruses, HCMV establishes lifelong latency in its host from which reactivation can occur and cause severe and fatal disease in immunocompromised individuals [8]. Cellular immune responses (MHC class Irestricted T-cells and natural killer (NK) cells) appear to be an important factor in both the control of acute infections and the establishment and maintenance of viral latency in the host [9-14]; however, the mechanisms by which Tcells affect HCMV replication are currently undefined. While cytotoxic T-cell activity has been shown to correlate with recovery from HCMV infection in patients $[15,16]$, recent studies suggest that immune cytokines such as tumor necrosis factor- $\alpha$ and interferons (IFNs) may have direct inhibitory effects on HCMV replication $[17,18]$. In particular, the involvement of IFNs as a means of curtailing viral replication without cellular elimination is consistent with the hypothesis that cytokines produced by activated immune cells play a direct role in the control of viral infections [19-21].

Type I IFNs (IFN- $\alpha$ and IFN- $\beta$ ) and type II IFN (IFN- $\gamma$ ) are important components of the host immune response to viral infections. IFN- $\alpha$ and IFN- $\beta$ are produced by most cells as a direct response to viral infection [22-24], while IFN- $\gamma$ is synthesized almost exclusively by activated NK cells and activated T-cells in response to virus-infected cells [25]. Both types of IFNs achieve their antiviral effects by binding to their respective receptors (IFN- $\alpha / \beta$ or IFN- $\gamma$ receptors), resulting in the activation of distinct but related Janus kinase/signal transducer and activator of transcription (Jak/STAT) pathways. The result is the transcriptional activation of IFN target genes and the synthesis of a number of proteins that interfere with viral replication (reviewed in [26]). Although IFNs are effective inhibitors of viruses such as vesicular stomatitis virus and encephalomyocarditis virus [26], almost all RNA and DNA viruses have evolved mechanisms to subvert the host IFN response $[21,26,27]$. For example, HCMV inhibits IFN-stimulated antiviral and immunoregulatory responses at multiple steps [24,28-32]. Likewise, the herpes simplex virus (HSV-1) protein ICP34.5 [33], the influenza A virus NS1 protein [34], the simian virus-5 V protein [35], the Sendai virus C protein [36], the hepatitis $\mathrm{C}$ virus (HCV) NS5A and E2 proteins [37] and the Ebola virus VP35 protein [38] have all been shown to block IFNmediated responses in infected cells. However, several studies have shown that viruses normally resistant to the effects of type I or type II IFNs separately, are susceptible to IFNs when used in combination. For example, IFN- $\alpha / \beta$ and IFN- $\gamma$ synergistically inhibit the replication of HSV-1 both in vitro and in vivo [20]. In addition, recent reports have indicated that IFNs used in combination have a syn- ergistic antiviral activity against severe acute respiratory syndrome-associated coronavirus (SARS-CoV) [39], HCV [40] and Lassa virus [41].

In the present study, we examined the effects of IFN- $\alpha$, IFN- $\beta$ and/or IFN- $\gamma$ on HCMV replication in human foreskin fibroblasts (HFFs). Treatment of HFFs with IFN- $\alpha$, IFN- $\beta$ or IFN- $\gamma$ separately inhibited HCMV replication by $\leq 40$-fold in both plaque reduction and viral growth assays. In contrast, treatment with IFN- $\alpha$ and IFN- $\gamma$ or IFN- $\beta$ and IFN- $\gamma$ inhibited HCMV replication 10-20 times greater than that achieved by each IFN separately. This effect was synergistic in nature and the mechanism of inhibition may involve, at least in part, the regulation of IE gene expression. As with HSV-1 [20], we have found that when used in combination, both type I and type II IFNs potently inhibit the replication of HCMV in vitro.

\section{Results \\ IFN- $\alpha$ l $\beta$ and IFN- $\gamma$ synergistically inhibit HCMV plaque formation}

The abilities of human IFN- $\alpha$, IFN- $\beta$ or IFN- $\gamma$ to inhibit the replication of HCMV were initially compared in a plaque reduction assay on HFFs. Viral plaque formation was reduced by 9-, 37- or 29-fold in fibroblasts treated with $100 \mathrm{IU} / \mathrm{ml}$ of IFN- $\alpha$, IFN- $\beta$ or IFN- $\gamma$, respectively (Table 1 ). To test the effects of combination IFN-treatments on viral plaque formation, HFFs were pre-treated with $100 \mathrm{IU} / \mathrm{ml}$ each of (1) IFN- $\alpha$ and IFN- $\beta$, (2) IFN- $\alpha$ and IFN- $\gamma$ or (3) IFN- $\beta$ and IFN- $\gamma$. As expected, the level of inhibition achieved with both IFN- $\alpha$ and IFN- $\beta$ was not greater than the level of inhibition achieved by both IFNs separately. In contrast, pre-treatment with both type I IFNs (IFN- $\alpha$ or IFN- $\beta$ ) and type II IFN (IFN- $\gamma$ ) reduced HCMV plaquing efficiency by 164- and 662-fold, respectively (Table 1). To eliminate the possibility that this effect was merely a result of doubling the total amount of IFNs per culture, we tested the inhibitory effects of $200 \mathrm{IU} / \mathrm{ml}$ of each IFN separately. Two-hundred IU/ml of IFN- $\alpha$, IFN- $\beta$ or IFN- $\gamma$ reduced HCMV plaque formation by only $11-, 37$ - or 30fold, respectively (Table 1). The level of inhibition was not significantly greater than the level of inhibition achieved by each IFN at concentrations of $100 \mathrm{IU} / \mathrm{ml}(\mathrm{P}>0.05)$, suggesting that the degree of inhibition observed can be attributed to the presence of two distinct types of IFNs.

Figure 1 shows a representative micrograph of HCMV plaque formation on IFN-treated HFFs. Consistent with the results in Table 1, HCMV plaque efficiency was reduced and plaque morphology was smaller in cultures treated with a combination of type I and type II IFNs (Figure $1 \mathrm{E}, \mathrm{F})$. This phenotype was also observed in cultures treated with IFN- $\gamma$ alone (Figure 1D), although the overall inhibitory effect of IFN- $\gamma$ was similar to that achieved in IFN- $\beta$-treated HFFs. 
Table I: Effect of IFN- $\alpha$, IFN- $\beta$ and/or IFN- $\gamma$ on HCMV plaque formation

\begin{tabular}{|c|c|c|c|}
\hline Treatment & $\mathrm{IU} / \mathrm{ml}^{\mathrm{a}}$ & Log (mean no. of plaques) \pm sem & Fold-inhibitionc \\
\hline Vehicle & --- & $3.34 \pm 0.02^{b}$ & --- \\
\hline IFN- $\alpha$ & 100 & $2.38 \pm 0.01^{*}$ & 9 \\
\hline IFN- $\alpha$ & 200 & $2.30 \pm 0.01 *$ & 11 \\
\hline IFN- $\beta$ & 100 & $1.77 \pm 0.05^{*}$ & 37 \\
\hline IFN- $\beta$ & 200 & $1.77 \pm 0.02 *$ & 37 \\
\hline IFN- $\gamma$ & 100 & $1.88 \pm 0.03 *$ & 29 \\
\hline IFN- $\gamma$ & 200 & $1.85 \pm 0.02^{*}$ & 30 \\
\hline IFN- $\alpha$ and IFN- $\beta$ & 100 & $1.95 \pm 0.04^{*}$ & 25 \\
\hline IFN- $\alpha$ and IFN- $\gamma$ & 100 & $1.13 \pm 0.09 *$ & 164 \\
\hline IFN $-\beta$ and IFN- $\gamma$ & 100 & $0.52 \pm 0.05^{*}$ & 662 \\
\hline IFN- $\alpha$, IFN- $\beta$ and IFN- $\gamma$ & 100 & $0.66 \pm 0.15^{*}$ & 512 \\
\hline
\end{tabular}

aHFFs were treated with either 100 or $200 \mathrm{IU} / \mathrm{ml}$ each of IFN- $\alpha$, IFN- $\beta$ or IFN- $\gamma$ (separately or in combination).

bMean \pm sem of viral plaque formation on HFFs observed in 3 replicates per group. Cultures were infected with 2000 PFU/well of Towne-GFP, and plaque numbers were determined $14 \mathrm{~d}$ p.i. by fluorescent microscopy.

cFold-inhibition was calculated as: I ( $([\log$ plaques / PFU in vehicle-treated] - [log plaques / PFU in IFN-treated])

* Significant reduction in plaque numbers of IFN-treated groups as compared to vehicle-treated groups is denoted by a single asterisk $(\mathrm{P}<0.00 \mathrm{I}$, one-way ANOVA and Tukey's post hoc $t$ test).
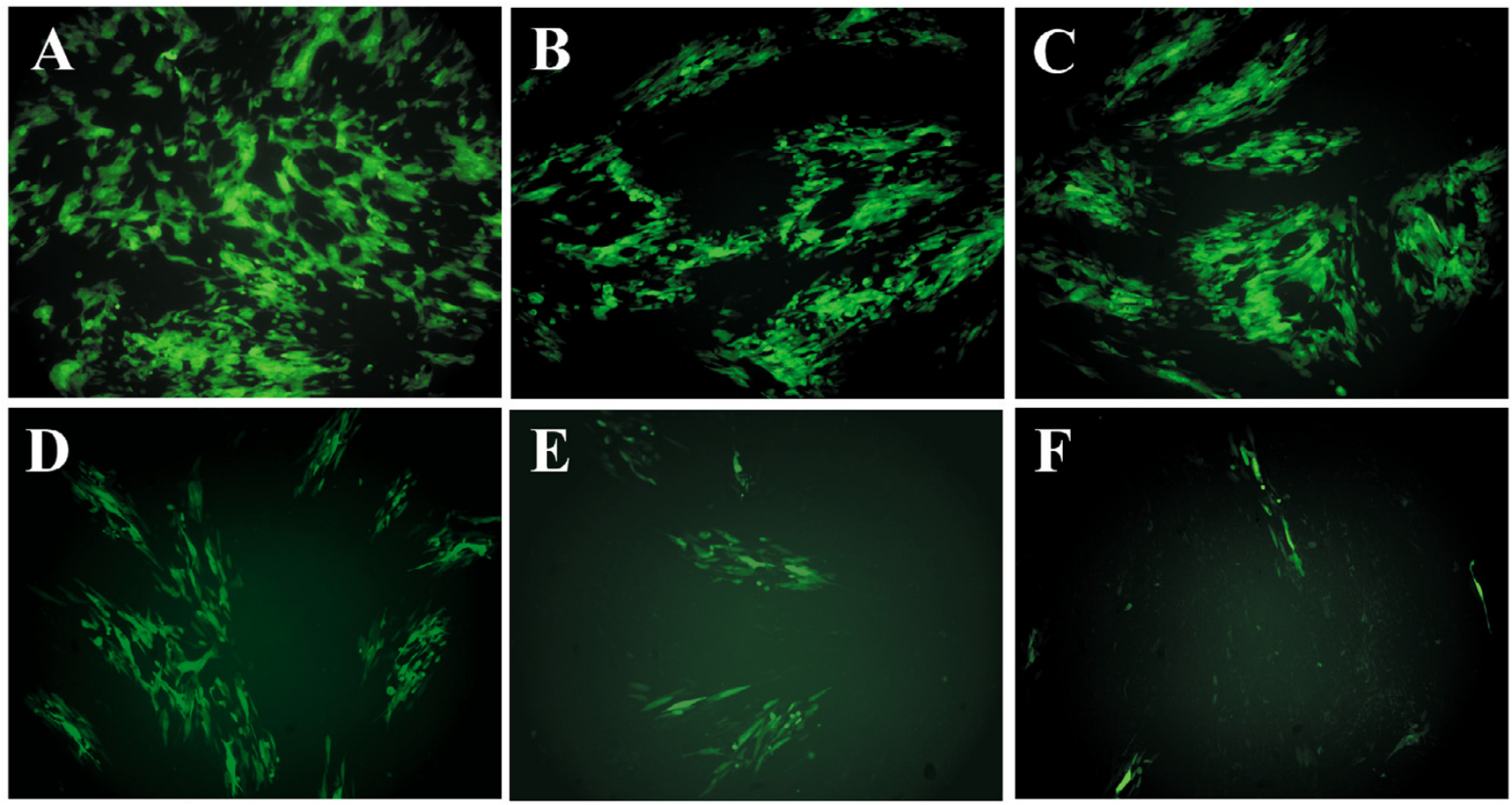

\section{Figure I}

IFN- $\alpha$, IFN- $\beta$ and/or IFN- $\gamma$ inhibit HCMV plaque formation on HFFs. HFFs were pre-treated with $(A)$ vehicle or I00 IU/ml each of (B) IFN- $\alpha$, (C) IFN- $\beta$, (D) IFN- $\gamma$, (E) IFN- $\alpha$ and IFN- $\gamma$ or (F) IFN- $\beta$ and IFN- $\gamma$. Monolayers were subsequently infected with 1000 PFU of HCMV strain Towne-GFP, and plaque numbers were determined II d p.i. by fluorescence microscopy. Plaques were determined by counting a minimum of 10 GFP-positive cells in one foci. 
Table 2: Degree of antiviral interaction between IFN- $\alpha / \beta$ and IFN- $\gamma$

\begin{tabular}{|c|c|c|c|}
\hline IFN Treatment ${ }^{a}\left(d_{a}+d_{b}\right)$ & $\mathrm{IC}_{90} \mathrm{D}_{\mathrm{a}}^{\mathrm{b}}$ & $I C_{90} D_{b}^{b}$ & interaction index ${ }^{c}$ \\
\hline $\mathrm{IFN}-\alpha+\mathrm{IFN}-\gamma$ & $300 \mathrm{IU} / \mathrm{ml}$ & $30 \mathrm{lU} / \mathrm{ml}$ & $0.05 \pm .03$ \\
\hline IFN $-\beta+$ IFN $-\gamma$ & $100 \mathrm{IU} / \mathrm{ml}$ & $30 \mathrm{lU} / \mathrm{ml}$ & $0.04 \pm .01$ \\
\hline
\end{tabular}

aHFFs were treated $12 \mathrm{~h}$ prior to infection with various combinations of type I IFNs (IFN- $\alpha$ or IFN- $\beta$ ) and type II IFN (IFN- $\gamma$ ). ${ }^{b} D_{a}$ and $D_{b}$ are the concentrations of each IFN separately that inhibit HCMV plaque formation on HFFs by $90 \%$ (IC ${ }_{90}$ ).

c Interaction index is a measure of the divergence between the amounts of IFNs that are observed to produce an inhibitory effect in combination ( $d_{a}$ $\left.+d_{b}\right)$ and the amounts that would achieve the same effect separately $\left(D_{a}\right.$ and $\left.D_{b}\right)$. Indexes less than I indicate synergy, indexes greater than I indicate antagonism and indexes equal to $I$ indicate additivity.

The antiviral activity of IFNs on HCMV plaque formation was further assessed by generating dose-response curves (Figure 2A). The level of inhibition achieved with individual IFN treatments was $\leq 8$-fold for IFN- $\alpha$ or IFN- $\beta$ and $\leq$ 18 -fold for IFN- $\gamma$ at all concentrations tested. In contrast, combination IFN treatments achieved levels of inhibition 2-18 times greater than the sum of each individual IFN treatment. To determine if the enhanced inhibition of HCMV observed in HFFs treated with both type I and type II IFNs was synergistic, we employed the synergistic analysis for the determination of the interaction of two drugs $[42,43]$. Interaction indexes were initially calculated from the data generated in the dose response experiments (Figure $2 \mathrm{~A}$ ) to assess the synergistic potential of type I and type II IFN treatment. An interaction index of $0.05 \pm 0.03$ for IFN- $\alpha$ and IFN- $\gamma$ combined and $0.04 \pm 0.01$ for IFN- $\beta$ and IFN- $\gamma$ combined indicated a high degree of synergy (Table 2). Additionally, synergy was confirmed by generating isobolograms in which concave isoboles are indicative of synergy while convex isoboles are indicative of an antagonistic effect (Figure 2B). Inhibitory concentrations were determined from dose response experiments, and $\mathrm{IC}_{95}$ isoboles were generated for HFFs treated with both IFN- $\alpha$ and IFN- $\gamma$ (Figure 2C, concave plot) and HFFs treated with both IFN- $\beta$ and IFN- $\gamma$ (Figure 2D, concave plot). Consistent with the interaction indexes determined (Table 2), concave isoboles shown in Figures 1C and 1D indicate a synergistic relationship between type I IFNs (IFN- $\alpha$ and IFN- $\beta$ ) and type II IFN (IFN- $\gamma$ ), suggesting action via distinct antiviral pathways.

IFN- $\alpha$ I $\beta$ and IFN- $\gamma$ synergistically inhibit HCMV replication To further characterize the inhibitory effect of type I IFNs (IFN- $\alpha$ or IFN- $\beta$ ) and type II IFN (IFN- $\gamma$ ) treatment, fourday viral growth assays were performed. In cultures treated with IFN- $\alpha$, IFN- $\beta$ or IFN- $\gamma$, viral replication was undetectable or below the lower limit of detection at 1 and 2 days (d) post-infection (p.i.). At $3 \mathrm{~d}$ p.i., however, HCMV replicated to average titers of 8350,1050 or 985 $\mathrm{PFU} / \mathrm{ml}$ in IFN- $\alpha$-, IFN- $\beta$ - or IFN- $\gamma$-treated cultures, respectively (Figure 3 ). While vehicle-treated cells replicated to average titers of $3.2 \times 10^{4} \mathrm{PFU} / \mathrm{ml}$, viral titers recovered from cells treated with IFNs separately were reduced by 6 , 23- or 25-fold, respectively. Moreover, at 4 d p.i., viral titers in cells treated with IFNs separately were equal to viral titers recovered from vehicle-treated cultures. Consistent with our plaque reduction assays, we observed a similar enhanced inhibitory effect when HFFs were treated with a combination of type I and type II IFNs. In cultures treated with $100 \mathrm{IU} / \mathrm{ml}$ each of IFN- $\alpha$ and IFN- $\gamma$ or IFN- $\beta$ and IFN- $\gamma$, HCMV replication was detectable beginning at $3 \mathrm{~d}$ p.i. yielding titers at or below the lower limit of detection of the assay. Compared to HCMV titers of $1 \times 10^{5} \mathrm{PFU} / \mathrm{ml}$ at $4 \mathrm{~d}$ p.i. in vehicle-treated HFFs, treatment with IFN- $\alpha$ and IFN- $\gamma$ or IFN- $\beta$ and IFN- $\gamma$ inhibited HCMV replication in HFFs by an average of 3125- or 5000-fold, respectively. When compared to ganciclovir (GCV)-treated cells, a known DNA synthesis inhibitor of HCMV, the level of inhibition achieved in GCV-treated cultures was comparable to that in IFN- $\alpha$ and IFN- $\gamma$ - or IFN- $\beta$ and IFN- $\gamma$-treated cultures at 3 and $4 \mathrm{~d}$ p.i. (Figure 3 ). In addition, the potent inhibitory effect observed in the presence of IFN- $\beta$ and IFN- $\gamma$ was maintained up to $11 \mathrm{~d}$ p.i. (Figure 3 , inset), indicating that the effect was not merely a delay in viral replication.

\section{Treatment with IFN- $\alpha$ I $\beta$ and IFN- $\gamma$ does not prevent $\mathrm{HCMV}$ entry into HFFs}

The HCMV replication cycle is a multistep process, beginning with viral attachment and entry into the host target cell [2]. To investigate the mechanism(s) by which IFN- $\alpha$ / $\beta$ and IFN- $\gamma$ synergistically inhibit HCMV replication, we first examined the effect of IFNs on HCMV entry into HFFs. Cells were treated with vehicle or IFNs for 12 hours (h) prior to infection with HCMV. Two h after viral adsorption, DNA was isolated from the HCMV-infected cells and PCR was used to amplify a $373 \mathrm{bp}$ fragment of the HCMV IE gene (Figure 4). For each treatment group, the PCR product yield increased as a function of viral multiplicity of infection (MOI). At all MOIs tested, the amount of PCR product amplified from HFFs treated with IFNs (Figure 4B-F) was comparable to that of vehicle- 

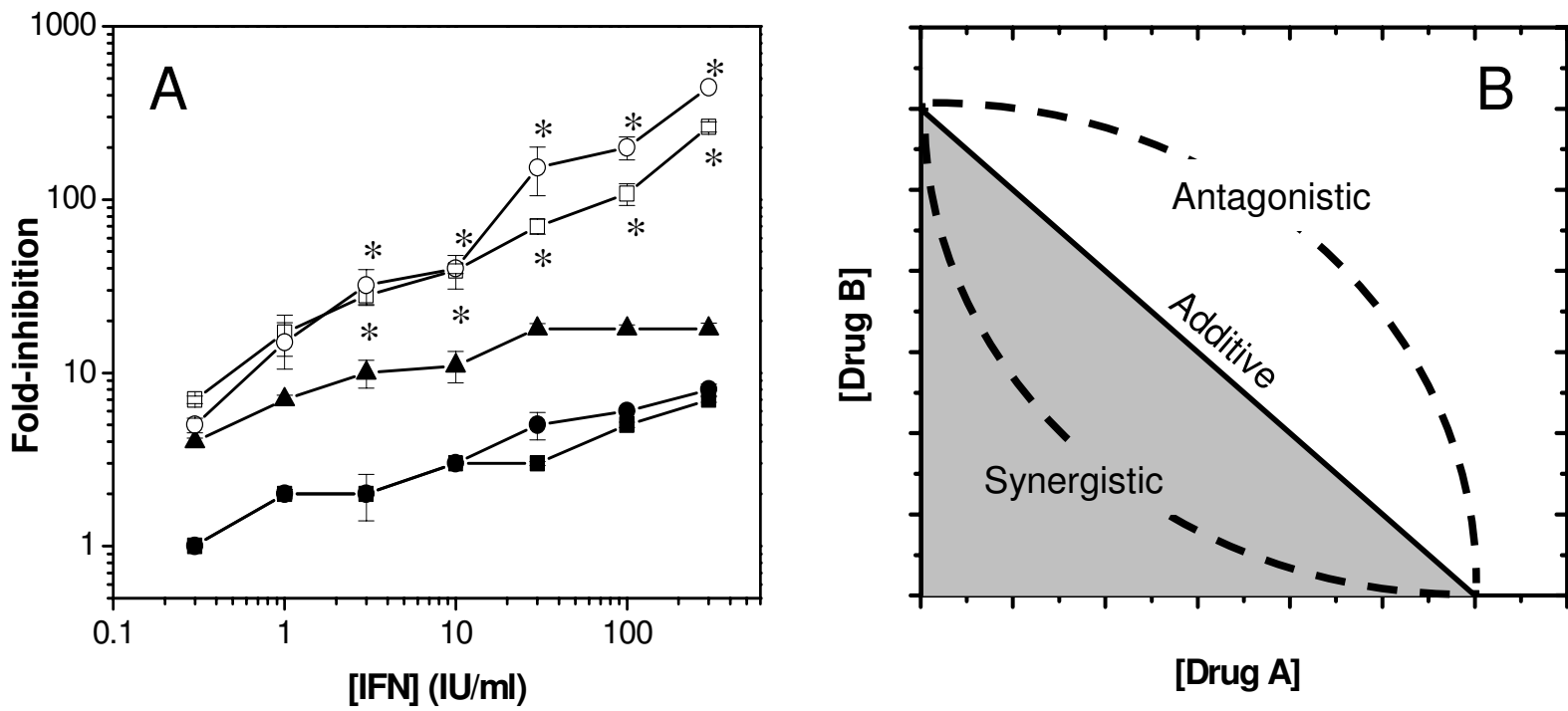

[Drug A]
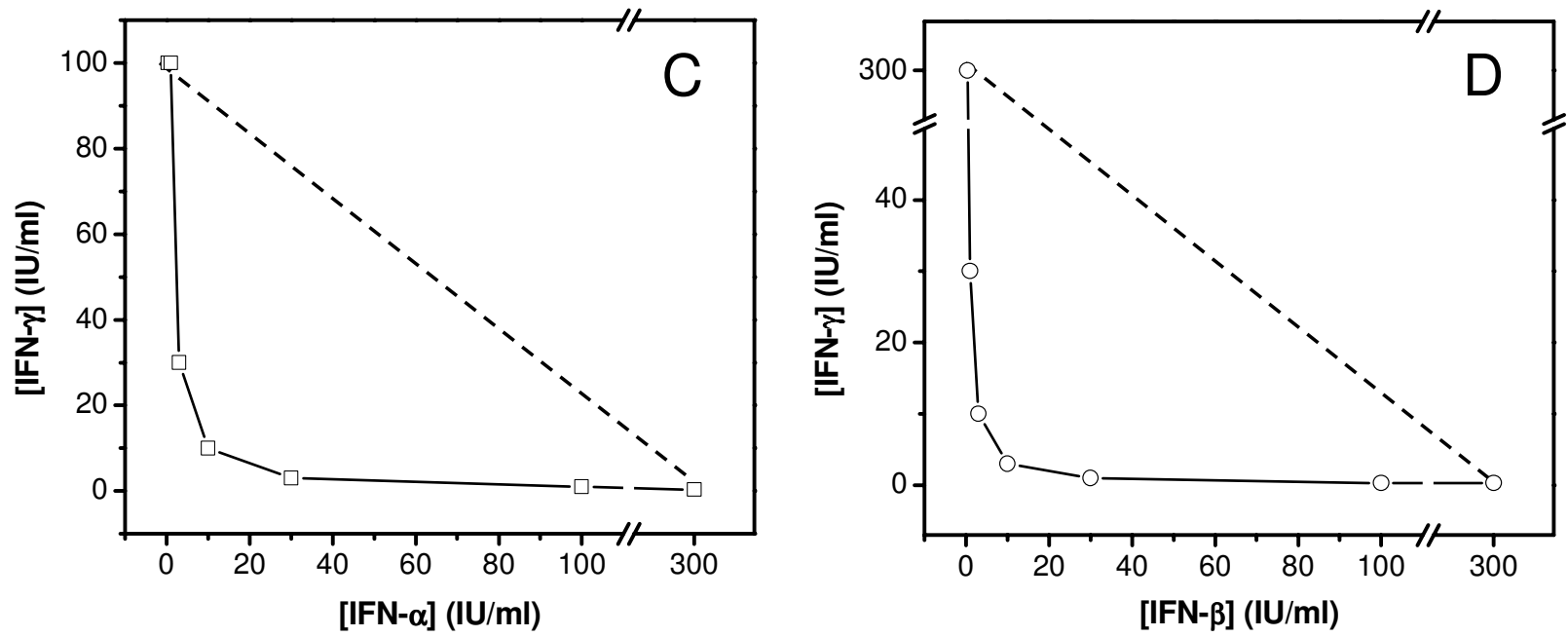

Figure 2

Type I IFNs (IFN- $\alpha$ and IFN- $\beta$ ) and type II IFN (IFN- $\gamma$ ) synergistically inhibit HCMV plaque formation on HFFs. (A) Viral plaque reduction assay. HFFs were treated with vehicle or increasing amounts of IFN- $\alpha(\mathbf{\square})$, IFN- $\beta(\mathbf{O})$, IFN- $\gamma(\mathbf{\Delta})$, IFN- $\alpha$ and IFN- $\gamma$ $(\square)$ or IFN- $\beta$ and IFN- $\gamma(\bigcirc)$ prior to infection with 400 PFU of Towne-GFP $(n=3)$. Fold-inhibition in IFN-treated groups as compared to vehicle-treated groups is plotted as a function of IFN concentration (IU/ml). Significant differences in fold-inhibition for HFFs treated with combination IFNs relative to cells treated with individual IFNs are denoted by a single asterisk $(\mathrm{P}<$ 0.00 I, one-way ANOVA and Tukey's post hoc $t$ test). (B) Illustration of a representative isobologram for a combination of two drugs. The solid line is the line of additivity. When the isobole lies below the line of additivity, the combinatorial effect of drug $A$ and drug $B$ is synergistic. When the isobole lies above the line of additivity, the combinatorial effect of drug $A$ and drug $B$ is antagonistic. Combination effect of (C) IFN- $\alpha$ and IFN- $\gamma$ and (D) IFN- $\beta$ and IFN- $\gamma$ on HCMV plaque formation on HFFs was plotted in an isobologram. Values used to generate the concave isoboles were derived from a dose response curve and represent a combination dose required to elicit $95 \%\left(\mathrm{IC}_{95}\right)$ inhibition of viral plaque formation on HFFs. The dashed line represents the theoretical line of additivity. 


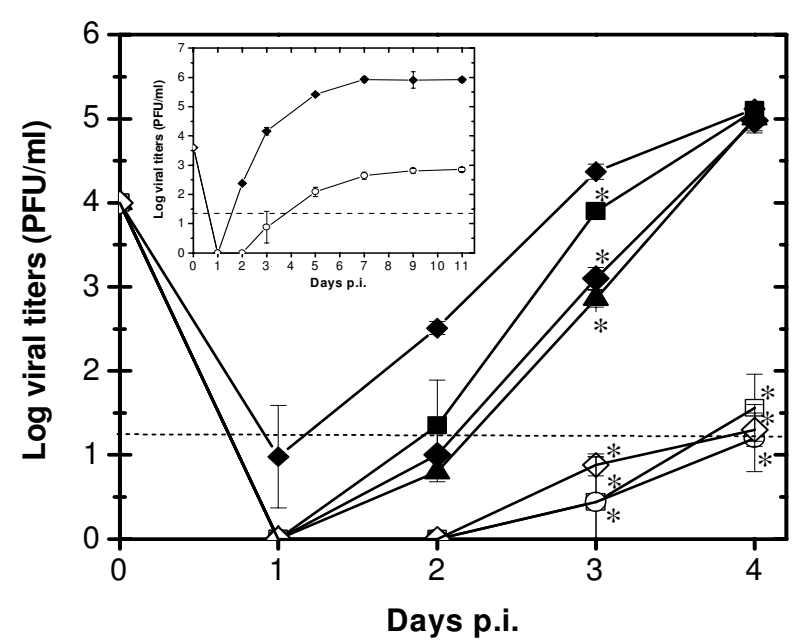

Figure 3

IFN- $\alpha$, IFN- $\beta$ and/or IFN- $\gamma$ inhibit HCMV replication in HFFs. HFFs were treated with vehicle or $100 \mathrm{IU} / \mathrm{ml}$ of IFNs $12 \mathrm{~h}$ prior to infection with $\mathrm{HCMV}$ at a MOI of 2.5: ( $\diamond)$ vehicle,

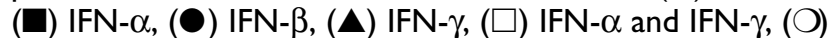
IFN- $\beta$ and IFN- $\gamma$ or $(\diamond) \mathrm{GCV}(100 \mu \mathrm{M})$. On the indicated $d$ p.i., average viral titers $(n=3)$ were determined by a microtiter plaque assay. HFFs were inoculated for $2 \mathrm{~h}$ with serially diluted lysed cultures. Plaque numbers were determined I I d p.i. by fluorescence microscopy. At $3 \mathrm{~d}$ p.i., all IFN treatments significantly reduced viral titers as compared to vehicle-treated cultures $(P<0.001$, one-way ANOVA and Tukey's post hoc $t$ test). At $4 \mathrm{~d}$ p.i., only cells treated with GCV or combination IFN treatments inhibited viral titers as compared to vehicle-treated HFFs $(P<0.001$, one-way ANOVA and Tukey's post hoc $t$ test). Significant reduction denoted by a single asterisk. Inset: Represents HCMV titers determined over II d for $(\diamond)$ vehicle-treated and $(O)$ IFN- $\beta$ and IFN- $\gamma$-treated HFFs. The dashed line represents the lower limit of detection of the plaque assay $(20 \mathrm{PFU} / \mathrm{ml})$ used to measure viral titers.

treated HFFs (Figure 4A). Co-amplification of a GAPDH 239 bp PCR product served as an internal loading control for normalization of PCR product between treatment groups (data not shown). The amplification of similar levels of PCR products from HFFs suggests that the synergistic inhibitory effect of IFN- $\alpha / \beta$ and IFN- $\gamma$ does not occur at the level of viral entry.

\section{IFN- $\alpha$ I $\beta$ and IFN- $\gamma$ inhibit HCMV IE mRNA expression}

HCMV gene expression is temporally regulated in that the IE genes (IE1 and IE2) are the first class of viral genes expressed after HCMV entry into the cell [44]. Although

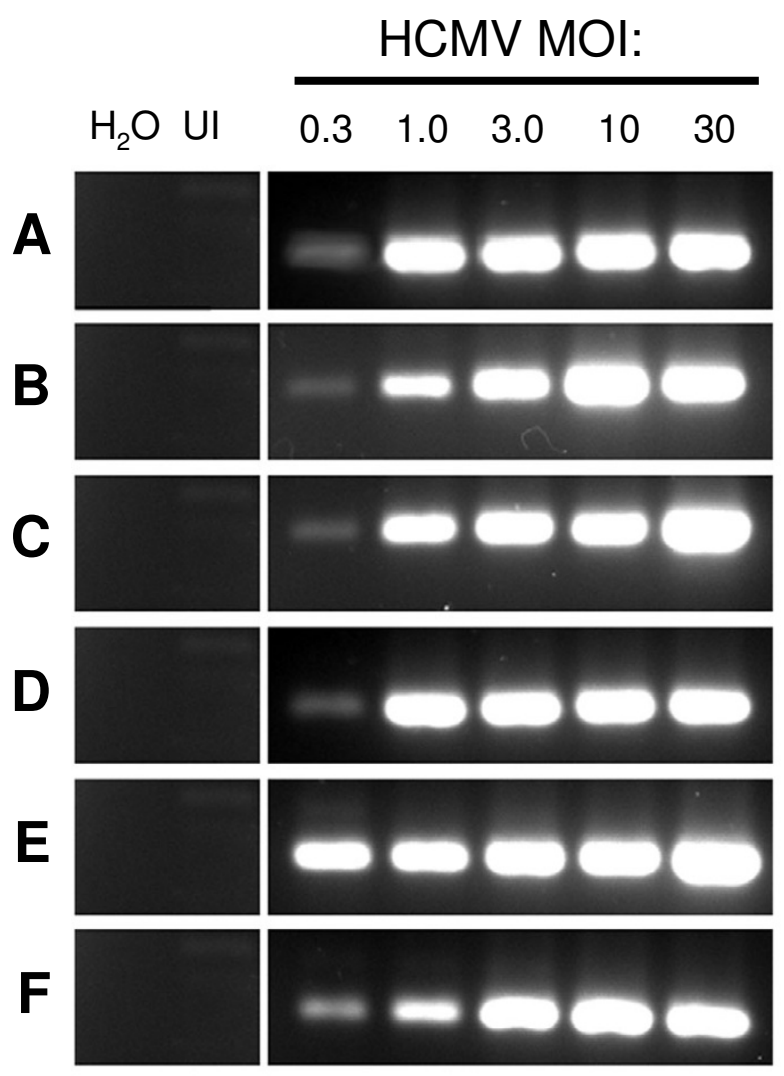

Figure 4

Inhibition of HCMV by IFN- $\alpha$, IFN- $\beta$ and/or IFN- $\gamma$ is not a result of decreased viral entry into cells. Ethidium bromidestained IE exon 4 PCR products amplified from HCMVinfected HFFs pre-treated with either vehicle (A) or $100 \mathrm{IU} /$ $\mathrm{ml}$ of IFN- $\alpha$ (B), IFN- $\beta$ (C), IFN- $\gamma$ (D), IFN- $\alpha$ and IFN- $\gamma$ (E) or IFN- $\beta$ and IFN- $\gamma(\mathrm{F})$. From left to right, PCR products were amplified from $\mathrm{H}_{2} \mathrm{O}$ control, $100 \mathrm{ng}$ of uninfected (UI) HFF DNA or $100 \mathrm{ng}$ of HCMV-infected HFF DNA harvested from cells inoculated for $2 \mathrm{~h}$ at MOls of 0.3 to 30 . GAPDH $\mathrm{PCR}$ products were run along side IE exon $4 \mathrm{PCR}$ products and served as internal loading controls (data not shown).

limited studies have examined the effect of IFN- $\beta$ or IFN$\gamma$ treatment on HCMV IE mRNA expression, the conclusions of these studies are conflicting, most likely due to differences in both IFN and cell type $[45,46]$. To assess the effect of IFN treatment on IE gene expression, real-time PCR analyses of IE1 and IE2 mRNA levels in IFN-treated cells were performed. Figure 5 summarizes the foldrepression in IE1 and IE2 mRNA levels in IFN-treated cultures as compared to vehicle-treated controls. At $6 \mathrm{~h}$ p.i., IE mRNA levels in HFFs treated individually with either IFN- $\alpha$ or IFN- $\gamma$ were inhibited by $<2$-fold, whereas in cells 


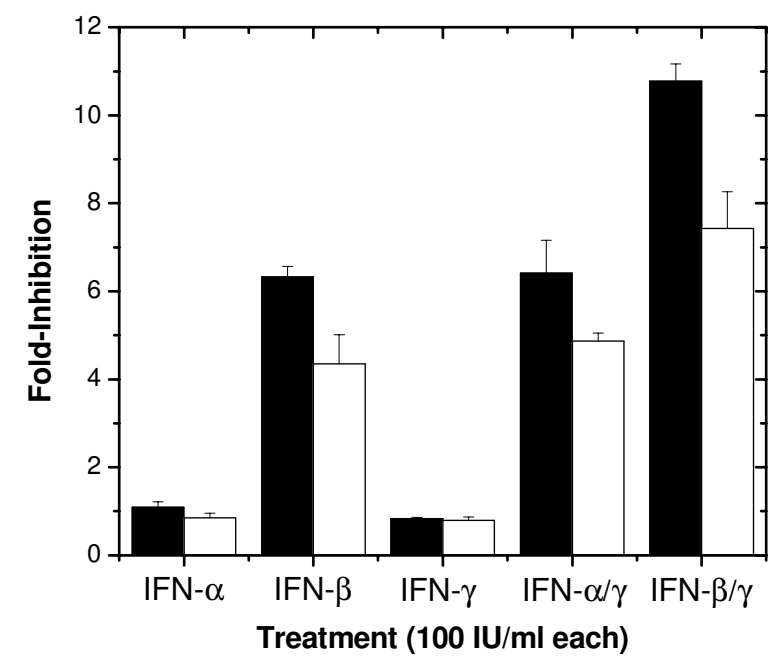

Figure 5

IFN- $\alpha$, IFN- $\beta$ and/or IFN- $\gamma$ inhibit HCMV IE mRNA expression. SYBR green real-time PCR analyses of IEI and IE2 mRNA expression in vehicle- or IFN-treated HFFs 6 h p.i. (n $=3$ ). Presented are fold-inhibition \pm standard deviation in IE I $(\square)$ and IE2 ( $\square$ ) mRNA expression in each treatment group. Differences in gene expression were determined as described in Methods.

treated with both IFN- $\alpha$ and IFN- $\gamma$, IE1 or IE2 mRNA expression was inhibited by 6- or 5-fold, respectively. A more enhanced inhibitory effect was observed in HFFs treated with both IFN- $\beta$ and IFN- $\gamma$. In these cultures, IE1 or IE2 mRNA expression was repressed by 11 - or 8 -fold, respectively. Interestingly, the degree of IE mRNA inhibition observed in HFFs treated with IFN- $\beta$ alone was greater than that observed in cultures treated with IFN- $\alpha$ alone, suggesting that type I IFN-mediated inhibition of IE mRNA expression is better facilitated by treatment with IFN- $\beta$ rather than IFN- $\alpha$.

\section{IFN- $\alpha$ I $\beta$ and IFN- $\gamma$ inhibit HCMV IE protein expression}

IE protein expression plays a pivotal role in controlling subsequent viral and cellular gene expression during productive HCMV infection [47], such that an inhibitory effect at this level would significantly impair viral replication. To determine whether the inhibitory block in IE mRNA expression correlated with decreased IE protein expression in IFN-treated cultures, western blot analyses were performed (Figure 6A). At 12 h p.i., a slight reduction in IE72 and IE86 protein expression was observed in HFFs treated with IFN- $\beta$, but not with IFN- $\alpha$ or IFN- $\gamma$.
Moreover, IE72 and IE86 protein expression was decreased in cells treated with both type I and type II IFNs, with the greatest inhibitory effect observed in HFFs treated with both IFN- $\beta$ and IFN- $\gamma$. This inhibitory block in IE protein expression was consistent throughout a $48 \mathrm{~h}$ time period (data not shown).

If IFN- $\alpha / \beta$ and IFN- $\gamma$ synergistically inhibit HCMV replication through inhibition of IE gene expression, we hypothesized that this inhibitory effect would be maintained after multiple rounds of viral replication. To address this question, IE protein expression was analyzed by indirect immunofluorescence over a 5-day period. For all treatment groups, IE protein expression was detected as early as $1 \mathrm{~h}$ p.i.; however, as viral replication progressed IE protein expression among IFN-treated groups varied (data not shown). Notably, by day 5 p.i., nearly $100 \%$ of the cells treated with vehicle, IFN- $\alpha$ or IFN- $\beta$ alone stained positive for IE72/86, and approximately $87 \%$ of the cells treated with IFN- $\gamma$ alone were expressing the IE proteins (Figure 6B-6E). In contrast, the percentage of cells expressing IE proteins was significantly reduced $(\mathrm{P}<$ 0.001 ) in the treatment groups that received combination IFNs, with only $46 \%$ of IFN- $\alpha$ and IFN- $\gamma$-treated HFFs and $21 \%$ of IFN- $\beta$ and IFN- $\gamma$-treated HFFs positive for IE72/86 (Figure 6F, 6G). The observed differences suggest that in cells treated with both type I and type II IFNs, IE expression is (1) differentially regulated and/or (2) viral spread is severely hindered.

\section{Discussion}

The immune response to viral infection is responsible for preventing viral dissemination and uncontrolled replication within the host. Following viral infection, type I IFNs are secreted by infected cells and function to induce an antiviral state in neighboring uninfected cells. Infiltrating immune cells, such as NK cells and macrophages, secrete numerous chemokines and cytokines that contribute to the overall antiviral response. Upon activation of the adaptive immune response, T-cells can further add to the milieu of immune cytokines present at the site of viral infection by secreting additional cytokines, including IFN$\gamma$. Although several studies have examined the effects of proinflammatory cytokines on HCMV replication in vitro, these studies are limited as they only examine the effect of one type of cytokine on viral replication rather than examining cytokines in combination. In support of the latter, recent studies have shown that type I and type II IFNs function, in synergy, to inhibit both RNA and DNA viruses, including HCV [41], SARS-CoV [39], Lassa virus [40] and HSV-1 [20]. These studies may more accurately represent the in vivo inflammatory response that results after viral infection. The results presented herein are consistent with this hypothesis and establish that type I (IFN- 

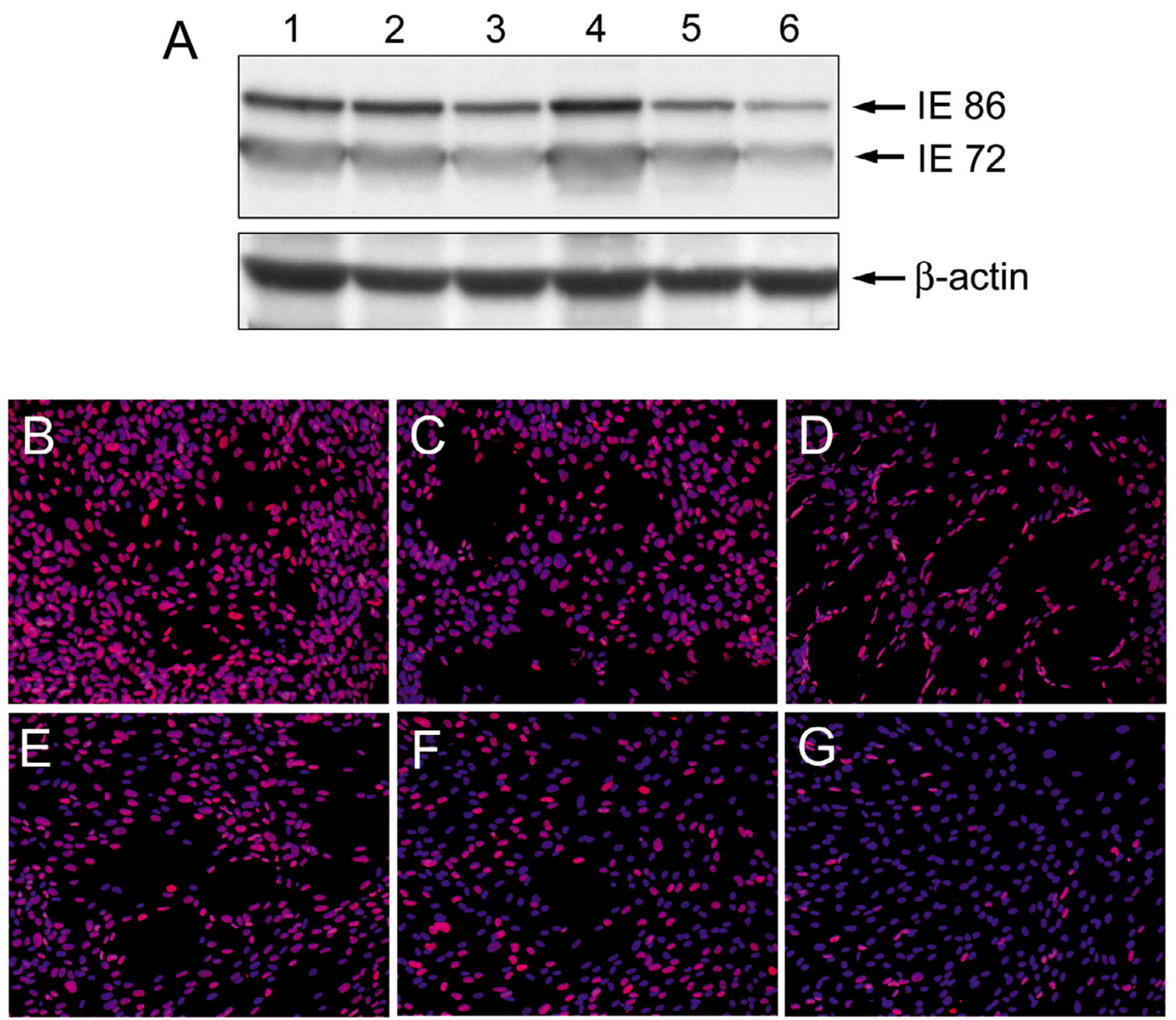

Figure 6

IFN- $\alpha$, IFN- $\beta$ and/or IFN- $\gamma$ inhibit HCMV IE protein expression. (A) HFFs were pre-treated with either vehicle (I) or I00 IU/ $\mathrm{ml}$ of IFN- $\alpha$ (2), IFN- $\beta$ (3), IFN- $\gamma(4)$, IFN- $\alpha$ and IFN- $\gamma$ (5) or IFN- $\beta$ and IFN- $\gamma(6)$ I $2 \mathrm{~h}$ prior to infection with HCMV. At $12 \mathrm{~h}$ p.i., cells were harvested and equal amounts of total protein were examined for IE protein (IE72, IE86) expression by western blot analyses. (B-G) Vehicle- or IFN-treated cells were infected with HCMV and the nuclear proteins IE72/86 were detected by indirect immunofluorescence $5 \mathrm{~d}$ p.i. Representative images (I00X) from cultures treated with (B) vehicle, (C) IFN- $\alpha$, (D) IFN$\beta$, (E) IFN- $\gamma$, (F) IFN- $\alpha$ and IFN- $\gamma$ or (G) IFN- $\beta$ and IFN- $\gamma$. Immunofluorescent labeling: HCMV IE72/86 - Alexa Fluor 568 (red), nucleus - DAPI (blue), overlaid (pink). 
$\alpha$ and IFN- $\beta$ ) and type II (IFN- $\gamma$ ) IFNs synergistically inhibit the replication of HCMV.

In the present study we have demonstrated that combination treatment with type I and type II IFNs renders cells non-permissive to HCMV replication in vitro. The inhibitory effect by IFN- $\alpha / \beta$ and IFN- $\gamma$ was synergistic in nature (Table 2, Figure 2C, 2D) and the degree of inhibition was not matched by increasing the concentrations of each individual IFN (Table 1, Figure 2A). These results indicate that the observed IFN-induced antiviral effects are a direct result of the presence of two distinct types of IFNs. Moreover, inhibition of HCMV replication in cells treated with IFN- $\alpha / \beta$ and IFN- $\gamma$ was observed in both HFF and embryonic lung fibroblasts (MRC5) (data not shown) infected with either Towne-GFP (see Methods) or another laboratory strain, AD169 (data not shown). The mechanism(s) by which HCMV replication is inhibited remains unclear. Type I and type II IFNs may synergize by acting on one or more different stages of the HCMV lytic cycle such as (1) viral attachment, (2) viral entry, (3) IE gene expression, (4) early gene expression, (5) DNA replication, (6) late gene expression, (7) virus assembly or (8) viral egress and maturation. To address the question of attachment and entry, PCR was used to amplify viral DNA from IFN-treated and vehicle-treated cultures shortly after infection. As previously observed [20,46], IFN treatment did not prevent viral entry into cells as indicated by equal PCR product yield from all treatment groups (Figure 4). These data indicate that IFNs exert their inhibitory effects at a step after viral attachment and entry.

Previously, Yamamoto, et al. (1987) demonstrated that treatment of cells with both IFN- $\alpha$ and IFN- $\gamma$ potently inhibits HCMV replication; however, this study neither determined whether the effect was synergistic nor identified the mechanism of inhibition. However, the authors suggested that IFN-mediated inhibition of HCMV might occur at or prior to early gene expression [48]. Similarly, over the course of our experiments utilizing the TowneGFP strain, it was noticed that very few cells expressed green fluorescent protein (GFP) when treated with IFN- $\alpha$ / $\beta$ and IFN- $\gamma$ together (data not shown). In this recombinant Towne strain, GFP expression is driven by the early promoter UL127. The lack of GFP-positive cells in IFN- $\alpha$ / $\beta$ and IFN- $\gamma$-treated groups suggested to us that the synergistic antiviral activities mediated by type I and type II IFNs occurred at a stage prior to early gene expression. Previous, studies have shown that type I or type II IFN treatment can inhibit HCMV IE mRNA expression [46] and/or HCMV IE protein expression $[45,46]$. Using real-time PCR, we showed that while IFN- $\alpha$, IFN- $\beta$ or IFN- $\gamma$ treatment inhibited IE mRNA expression by $2-6$ fold at $6 \mathrm{~h}$ p.i., combination IFN- $\alpha$ and IFN- $\gamma$ or IFN- $\beta$ and IFN- $\gamma$ treatment inhibited IE mRNA expression by $6-11$ fold. Of note, this inhibitory effect was abolished by $24 \mathrm{~h}$ p.i. (data not shown), suggesting that IE mRNA expression is delayed by IFN treatment. The observed decrease in viral IE mRNA expression was accompanied by a decrease in IE protein expression, as viral IE protein expression was reduced in HFFs treated with both type I and type II IFNs (Figure 6A). Furthermore, immunofluorescent microscopy of IE protein expression revealed that nearly $100 \%$ of vehicle- and individual IFN-treated cells expressed IE72/ 865 d p.i., as compared to $46 \%$ or $21 \%$ of cells treated with IFN- $\alpha$ and IFN- $\gamma$ or IFN- $\beta$ and IFN- $\gamma$, respectively (Figure 6B-6G). It appears that although individual IFN treatment results in a marginal inhibition in IE expression early in infection, the effect is not maintained as demonstrated by high viral titers at $4 \mathrm{~d}$ p.i. (Figure 3 ) and increased IE protein expression at 5 d p.i. (Figure 6A-6E). Additionally, HCMV cytopathic effect, characterized by enlarged cells containing intranuclear and cytoplasmic inclusions, increased over time in vehicle- and individual IFN-treated groups, while morphology was unchanged in cells treated with IFN- $\alpha / \beta$ and IFN- $\gamma$ (data not shown). Collectively, these data suggest that the synergistic inhibition of HCMV replication by IFN- $\alpha / \beta$ and IFN- $\gamma$ may involve, at least in part, the regulation of IE gene expression. The significance of an inhibitory block at this level is evident when the phenotype of IE1 mutant viruses is considered. Greaves and colleagues have demonstrated that HCMV IE1 mutants exhibit a diminished replication efficiency and a reduced ability to form plaques, as well as defective early gene expression $[47,49,50]$. Interestingly, in the presence of both type I and type II IFNs, HCMV shows similar replication and gene expression defects. Although our data suggest that IE gene regulation contributes to the synergistic inhibition of HCMV replication by IFN- $\alpha / \beta$ and IFN- $\gamma$, other mechanisms may also affect this dramatic response. Accordingly, the decrease in IE protein levels exceeds that in IE mRNA levels in response to IFN$\alpha / \beta$ and IFN- $\gamma$, suggesting that additional regulation at the level of translation, post-translational processing and/or protein stability may be involved. Delineating the other putative regulatory mechanisms that contribute to IFN- $\alpha$ / $\beta$ and IFN- $\gamma$ synergistic inhibition of HCMV replication is the focus of ongoing studies.

Type I IFNs (IFN- $\alpha$ and IFN- $\beta$ ) and type II IFN (IFN- $\gamma$ ) activate distinct but related Jak/STAT signal cascades resulting in the transcription of several hundred IFN-stimulated genes [26]. Although similar genes are activated by all three IFNs, Der, et al. (1998) have identified numerous genes differentially regulated by IFN- $\alpha$, IFN- $\beta$ or IFN- $\gamma$ [51]. In particular, IFN- $\beta$ stimulation induces twice as many genes as compared to IFN- $\alpha$. This differential regulation of IFN-induced genes may explain in part the fact that the level of inhibition observed in HFFs treated with both IFN- $\beta$ and IFN- $\gamma$ was consistently greater than that 
observed in cells treated with both IFN- $\alpha$ and IFN- $\gamma$, although both IFN- $\alpha$ and IFN- $\beta$ bind to the same receptor. Similarly, when compared individually, IFN- $\beta$ consistently inhibited HCMV replication and IE gene expression to levels greater than IFN- $\alpha$. Therefore, to better understand the cellular factors involved in the synergistic inhibition of HCMV, the profile of IFN-stimulated genes present in cells treated with both type I and type II IFNs should be further examined.

\section{Conclusion}

Guidotti and Chisari have reported a model of noncytolytic control of viral infections by the innate and adaptive immune response, in which cytokines are implicated as having a direct role in viral clearance [21]. Here we demonstrate that IFN- $\gamma$, together with the innate IFNs (IFN- $\alpha / \beta$ ) synergistically inhibits the replication of HCMV in vitro. We hypothesize that IFN- $\gamma$ produced by activated cells of the adaptive immune response may potentially synergize with endogenous type I IFNs to inhibit HCMV dissemination and facilitate the establishment and/or maintenance of latency in the host. Further studies are required to evaluate the role(s) of both type I and type II IFNs in the regulation of HCMV replication.

\section{Methods \\ Cells, viruses and interferons}

HFFs (Viromed, Minneapolis, MN) were maintained in minimal essential medium (MEM) supplemented with $10 \%$ fetal bovine serum, penicillin $\mathrm{G}(100 \mathrm{U} / \mathrm{ml})$, streptomycin $(100 \mathrm{mg} / \mathrm{ml}), 2 \mathrm{mM}$ L-glutamine, $1 \mathrm{mM}$ sodium pyruvate and $100 \mu \mathrm{M}$ non-essential amino acids at $37^{\circ} \mathrm{C}$ in $5 \% \mathrm{CO}_{2}$. HCMV strain RVdlMwt-GFP was propagated in HFFs as previously described [52]. RVdlMwt-GFP, referred to as Towne-GFP throughout this manuscript, is a recombinant of HCMV strain Towne that expresses GFP under the control of the early promoter UL127. This virus was kindly donated by Mark F. Stinski and has been previously described [53].

Recombinant human universal IFN- $\alpha$, IFN- $\beta$ and IFN- $\gamma$ (PBL Biomedical Laboratories, New Brunswick, NJ) were added to cell cultures $12 \mathrm{~h}$ prior to HCMV infection and maintained after viral infection. Concentrations of 100 $\mathrm{IU} / \mathrm{ml}$ of each IFN were used in all experiments unless stated otherwise.

\section{Plaque reduction and viral replication assays}

For plaque reduction assays, vehicle- and IFN-treated HFFs were infected with a fixed inoculum of Towne-GFP. After $2 \mathrm{~h}$ adsorption, the inoculum was removed and medium containing 1.0\% methylcellulose (Fisher Scientific, Houston, TX) and the respective IFN(s) was added to the cells. Plaque numbers were determined $14 \mathrm{~d}$ later by fluorescent microscopy (Nikon TE300 inverted epifluorescent microscope, Nikon USA, Lewisville, TX).

For viral replication assays, vehicle- and IFN-treated HFFs were infected with Towne-GFP at a MOI of 2.5. After $2 \mathrm{~h}$ adsorption, the inoculum was removed, monolayers were washed twice with $1 \mathrm{X}$ PBS, and fresh IFN-containing medium was returned to each well. For GCV-treated groups, $100 \mu \mathrm{M}$ GCV (Sigma, St. Louis, MO) was added to culture medium immediately following infection. One, 2, 3 or $4 \mathrm{~d}$ p.i. cells and medium were harvested and titers of infectious virus were determined by a microtiter plaque assay on HFFs [20].

\section{Synergy assays}

To determine the degree of antiviral interaction between type I and type II IFNs, interaction indexes were calculated using the inequalities: $d_{a} / D_{a}+d_{b} / D_{b}>1$ and $d_{a} / D_{a}+d_{b} / D_{b}$ $<1$, where $\mathrm{d}_{\mathrm{a}}$ and $\mathrm{d}_{\mathrm{b}}$ are the IFN concentrations needed to jointly produce the effect under consideration, and $\mathrm{D}_{\mathrm{a}}$ and $\mathrm{D}_{\mathrm{b}}$ are the IFN concentrations capable of producing the effect on their own, termed isoeffective doses [42]. Interaction index values of less than 1 indicate synergism, interaction index values greater than 1 indicate antagonism and interaction index values equal to 1 indicate additivity. Isobolograms were also generated to geometrically assess the degree of antiviral interaction between type I and type II IFNs, as previously described [43]. Using the guidelines described by Berenbaum [43], isoboles were generated for $\mathrm{IC}_{95}$ values at various concentrations of IFN- $\alpha$ or IFN- $\beta$ in the presence of various concentrations of IFN- $\gamma$. Concave isoboles are indicative of synergy while convex isoboles are indicative of an antagonistic effect (Figure 2B). For all synergy experiments, HCMV plaque reduction assays were conducted as described above.

\section{Viral entry assay}

Vehicle- and IFN-treated HFFs were inoculated with Towne-GFP at MOIs of $0.3,1,3,10$ or 30 . After $2 \mathrm{~h}$ adsorption, the inoculi were removed, cells were washed twice with $1 \mathrm{X}$ PBS, and subsequently treated with $0.05 \%$ trypsin for 5 minutes to ensure the release of virus that had adhered but had not entered the cells. Cells were pelleted and washed twice with 1X PBS to remove trypsin and non-adhered virus. DNA was isolated from each sample by a standard phenol:chloroform DNA extraction procedure [54], and HCMV-specific oligonucleotide primers were used to amplify a 373 bp product corresponding to exon 4 of the HCMV IE gene, as described previously [55]. PCR products were resolved in a $2 \%$ agarose gel and imaged using an Alpha Innotech gel documentation system (Alpha Innotech, Corp., San Leandro, CA). 


\section{Real-time PCR}

Vehicle- and IFN-treated HFFs were infected with TowneGFP at a MOI of 2.5. Six h p.i., total RNA was prepared using a RNeasy Mini Prep kit (Qiagen, Inc., Valencia, CA) according to the manufacturer's instructions. Samples were treated with DNase I (Ambion, Inc., Austin, TX), RNA concentration and purity were determined spectrophotometrically $\left(\mathrm{A}_{260} / \mathrm{A}_{280}\right)$ and $250 \mathrm{ng}$ was reverse transcribed in a total volume of $20 \mu \mathrm{l}$ using the iScript cDNA Synthesis Kit (Biorad, Hercules, CA) according to the manufacturer's instructions. For real-time PCR, $1 \mu \mathrm{l}$ of cDNA was amplified in $1 \mathrm{X}$ iQ SYBR Green Supermix containing specific primer pairs using the iCycler iQ RealTime PCR Detection System (Biorad). The optimal primer concentrations and sequences were as follows: $200 \mathrm{nM}$ IE1, sense 5' CAAGTGACCGAGGATTGCAA 3', antisense 5' CACCATGTCCACTCGAACCTT 3' ; 200 nM IE2, sense 5' TGACCGAGGATTGCAACGA 3', antisense 5' CGGCATGATTGACAGCCTG 3' [56]; 100 nM 18S rRNA, sense 5' GAGGGAGCCTGAGAAACGG 3', antisense 5' GTCGGGAGTGGGTAATTTGC 3'. All samples were run on the same plate where those for the internal control (18S rRNA) and those for the genes of interest were each run in triplicate, for each of 3 independent RNA preparations. PCR parameters were as follows: an initial step to denature at $95^{\circ} \mathrm{C}$ for 30 seconds followed by 40 cycles at $95^{\circ} \mathrm{C}$ for 15 seconds and anneal/extend at $60^{\circ} \mathrm{C}$ for 45 seconds. Following amplification, melt curves were generated to confirm the specificity of each primer pair with 80 cycles of increasing increments of $0.5^{\circ} \mathrm{C}$ beginning with $55^{\circ} \mathrm{C}$ for 30 seconds. Relative quantification of the target genes in comparison to the $18 \mathrm{~S}$ reference gene was determined by calculating the relative expression ratio $(\mathrm{R})$ of each target gene as follows: $\mathrm{R}=\left(\mathrm{E}_{\text {target }}\right) \Delta \mathrm{CT}$ (vehicle-sample)/ $\left(\mathrm{E}_{18 \mathrm{~S}}\right) \Delta \mathrm{CT}$ (vehicle-sample) [57]. Differences in gene expression between the IFN-treated cells and the vehicle-treated control cells were expressed as fold-inhibition.

\section{Western blotting}

Vehicle- and IFN-treated HFFs were infected with TowneGFP at a MOI of 2.5. Twelve h p.i., the cells were harvested in $500 \mu \mathrm{l}$ of 1X RIPA buffer containing a protease inhibitor cocktail (Roche Applied Science, Indianapolis, IN) and $1 \mathrm{mM}$ PMSF. Lysates were sheared 3X with a 27G 1/2 needle and cell debris was pelleted by centrifugation at 14,000 r.p.m. at $4^{\circ} \mathrm{C}$. Total protein concentrations from cleared supernatants were estimated with a Micro BCA ${ }^{\mathrm{TM}}$ Protein Assay Kit (Pierce, Rockford, IL), $50 \mu \mathrm{g}$ of total protein were resolved on 10\% SDS-polyacrylamide gels and transferred by blotting to PVDF membranes (Amersham Biosciences, Piscataway, NJ). Non-specific reactivity was blocked with 5\% nonfat dried milk in Tris-buffered saline containing $0.1 \%$ Tween-20 (TBST) for $1 \mathrm{~h}$ at room temperature and blots were incubated for $1 \mathrm{~h}$ at room temperature with a polyclonal antibody that recognizes the
HCMV IE proteins (IE72/86), kindly provided by Daniel N. Streblow [58]. The blots were then washed in TBST and incubated with donkey anti-rabbit IgG conjugated to horseradish peroxidase (1:5000; Amersham Biosciences) for $1 \mathrm{~h}$ at room temperature. Antigen-antibody complexes were detected using an enhanced chemiluminescence system (Amersham Biosciences). Blots were subsequently washed in TBST and tested for immunoreactivity to a rabbit polyclonal antibody to human $\beta$-actin (Sigma; loading control).

\section{Indirect immunofluorescence}

Vehicle- and IFN-treated HFFs were infected with TowneGFP at a MOI of 1.0. Five d p.i., cells were washed $3 \mathrm{X}$ with 1X PBS, fixed with 1:1 methanol/acetone for 10 minutes at room temperature, washed again with $1 \mathrm{X}$ PBS, and blocked with $4 \%$ BSA/PBS for 15 minutes at room temperature. Cells were incubated for $1 \mathrm{~h}$ at $37^{\circ} \mathrm{C}$ with a HCMV IE antibody (IE72/86 kD; Chemicon \#MAB810, Temecula, CA) diluted 1:200 in 0.5\% BSA/PBS. Cells were then stained with 1:50 Alexa Fluor 568-conjugated goat anti-mouse IgG $\mathrm{F}\left(\mathrm{ab}^{\prime}\right)_{2}$ (Molecular Probes, Eugene, OR) for 30 minutes at $37^{\circ} \mathrm{C}$, followed by a 2 minute incubation with $1 \mu \mathrm{M} 4$ ',6-diamidino-2-phenylindole, dihydrochloride (DAPI; Molecular Probes) at room temperature. Cells were coverslipped and mounted in Prolong Antifade mounting medium (Molecular Probes), visualized on a Zeiss Axio Plan II microscope (Thornwood, NY) and images were analyzed with deconvolution SlideBook ${ }^{\mathrm{TM}} 4.0$ Intelligent Imaging software (Intelligent Imaging Innovations, Denver, CO). To determine the number of HCMVinfected cells, three fields of view (100X) for each treatment group were considered and the percent of IE-positive cells was calculated as: (average number of IE-stained cells/average number of DAPI-stained cells $) \times 100$.

\section{Statistics}

Data are presented as the means \pm standard error of the means (sem). Data from IFN-treated groups were compared to vehicle-treated groups and significant differences were determined by one-way analysis of variance (ANOVA) followed by Tukey's post hoc $t$ test (GraphPad Prism $^{\circ}$ Home, San Diego, CA).

\section{Competing interests}

The author(s) declare that they have no competing interests.

\section{Authors' contributions}

BS and HL conceived of the study, participated in the experimental design, performed all experiments and drafted the manuscript. RG and CM participated in the coordination and design of the study. All authors read and approved the final manuscript. 


\section{Acknowledgements}

This work was supported by the National Institutes of Health (AI054626, Al054238, RR018229, and CA0892I; R.F.G.) and (HD045768; C.A.M.). Bruno Sainz is a recipient of a National Research Service Award from the $\mathrm{NIH}$ (AI05438I8). The authors would like to thank Dr. Mark F. Stinski (University of lowa, lowa City, lowa) for kindly supplying the recombinant virus Towne-GFP and Dr. Daniel N. Streblow (Oregon Health Sciences University, Portland, OR) for kindly donating the HCMV IE antibody. We also thank Dr. Aline Scandurro for critical review of this manuscript and Dr. Joseph Vaccaro and Joshua Costin for their expertise in statistical analyses. We are also indebted to Dr. David Woodhall for his expertise and assistance with HCMV propagation and plaque assays.

\section{References}

I. Trincado DE, Rawlinson WD: Congenital and perinatal infections with cytomegalovirus. J Paediatr Child Health 200I, 37:187-192.

2. Mocarski ES: Cytomegalovirus Biology and Replication. In The Human Herpesviruses Edited by: Roizman B and Whitley RJ. New York, Raven Press Ltd; 1993.

3. Nerheim PL, Meier JL, Vasef MA, Li WG, Hu L, Rice JB, Gavrila D, Richenbacher WE, Weintraub NL: Enhanced cytomegalovirus infection in atherosclerotic human blood vessels. Am J Pathol 2004, 164:589-600.

4. Melnick JL, Adam E, Debakey ME: Cytomegalovirus and atherosclerosis. Eur Heart J 1993, I4 Suppl K:30-38.

5. Britt W: Congenital cytomegalovirus infection. In Sexually transmitted diseases and adverse outcomes of pregnancy Ist edition. Edited by: Hitchcock PJ and Wasserheit JN. Washington D.C., ASM Press; 1999:269-281.

6. Song BH, Lee GC, Moon MS, Cho YH, Lee CH: Human cytomegalovirus binding to heparan sulfate proteoglycans on the cell surface and/or entry stimulates the expression of human leukocyte antigen class I. J Gen Virol 200I, 82:2405-24I3.

7. Wang X, Huong SM, Chiu ML, Raab-Traub N, Huang ES: Epidermal growth factor receptor is a cellular receptor for human cytomegalovirus. Nature 2003, 424:456-46I.

8. Huang ES, Kowalik TF: Molecular Aspects of Human Cytomegalovirus Diseases. Edited by: Becker Y, Darai G and Huang ES. Berlin, Springer; 1993.

9. Dunn HS, Haney DJ, Ghanekar SA, Stepick-Biek P, Lewis DB, Maecker HT: Dynamics of CD4 and CD8 T cell responses to cytomegalovirus in healthy human donors. Infect Dis 2002, 186: I5-22.

10. Falk CS, Mach M, Schendel DJ, Weiss EH, Hilgert I, Hahn G: NK cell activity during human cytomegalovirus infection is dominated by US2-I I-mediated HLA class I down-regulation. J Immunol 2002, 169:3257-3266.

II. Wills MR, Carmichael AJ, Mynard K, Jin X, Weekes MP, Plachter B, Sissons JG: The human cytotoxic T-lymphocyte (CTL) response to cytomegalovirus is dominated by structural protein pp65: frequency, specificity, and T-cell receptor usage of pp65-specific CTL. J Virol 1996, 70:7569-7579.

12. Gillespie GM, Wills MR, Appay V, O'Callaghan C, Murphy M, Smith N, Sissons P, Rowland-Jones S, Bell JI, Moss PA: Functional heterogeneity and high frequencies of cytomegalovirus-specific CD8(+) T lymphocytes in healthy seropositive donors. J Virol 2000, 74:8I40-8I50.

13. Gamadia LE, van Leeuwen EM, Remmerswaal EB, Yong SL, Surachno S, Wertheim-van Dillen PM, Ten Berge IJ, Van Lier RA: The size and phenotype of virus-specific $T$ cell populations is determined by repetitive antigenic stimulation and environmental cytokines. J Immunol 2004, | 72:6 |07-6 | |4.

14. Sester M, Sester U, Gartner BC, Girndt M, Meyerhans A, Kohler H: Dominance of virus-specific CD8 $T$ cells in human primary cytomegalovirus infection. J Am Soc Nephrol 2002, 13:2577-2584.

15. Rook AH, Quinnan GV Jr, Frederick WJ, Manischewitz JF, Kirmani N, Dantzler T, Lee BB, Currier CB Jr: Importance of cytotoxic lymphocytes during cytomegalovirus infection in renal transplant recipients. Am J Med 1984, 76:385-392.

16. Starr SE, Smiley L, Wlodaver C, Friedman HM, Plotkin SA, Barker C Natural killing of cytomegalovirus-infected targets in rena transplant recipients. Transplantation 1984, 37:161-164.
17. Torigoe S, Campbell DE, Starr SE: Cytokines released by human peripheral blood mononuclear cells inhibit the production of early and late cytomegalovirus proteins. Microbiol Immunol 1997, $41: 403-413$.

18. Weinberg A, Wohl DA, MaWhinney S, Barrett RJ, Brown DG, Glomb $\mathrm{N}$, van der Horst $\mathrm{C}$ : Cytomegalovirus-specific IFN-gamma production is associated with protection against cytomegalovirus reactivation in HIV-infected patients on highly active antiretroviral therapy. Aids 2003, 17:2445-2450.

19. Compton T, Kurt-Jones EA, Boehme KW, Belko J, Latz E, Golenbock DT, Finberg RW: Human cytomegalovirus activates inflammatory cytokine responses via CDI4 and Toll-like receptor 2 . J Virol 2003, 77:4588-4596.

20. Sainz B Jr, Halford WP: Alpha/Beta interferon and gamma interferon synergize to inhibit the replication of herpes simplex virus type I.J Virol 2002, 76: II54I-II550.

21. Guidotti LG, Chisari FV: Noncytolytic control of viral infections by the innate and adaptive immune response. Annu Rev Immunol 200I, 19:65-9I.

22. Rodriguez JE, Loepfe TR, Swack NS: Beta interferon production in primed and unprimed cells infected with human cytomegalovirus. Arch Virol 1987, 94: 177-189.

23. Thomson A: The cytokine handbook, 3rd ed. San Diego, CA, Academic Press; 1998.

24. Miller DM, Zhang Y, Rahill BM, Waldman WJ, Sedmak DD: Human cytomegalovirus inhibits IFN-alpha-stimulated antiviral and immunoregulatory responses by blocking multiple levels of IFN-alpha signal transduction. J Immunol 1999, 162:6 I07-6 I I3.

25. Pfeffer LM, Dinarello CA, Herberman RB, Williams BR, Borden EC Bordens R, Walter MR, Nagabhushan TL, Trotta PP, Pestka S: Biological properties of recombinant alpha-interferons: 40th anniversary of the discovery of interferons. Cancer Res 1998 , 58:2489-2499.

26. Goodbourn S, Didcock L, Randall RE: Interferons: cell signalling, immune modulation, antiviral response and virus countermeasures. J Gen Virol 2000, 81:234I-2364.

27. Katze MG, He Y, Gale M Jr: Viruses and interferon: a fight for supremacy. Nat Rev Immunol 2002, 2:675-687.

28. Miller DM, Rahill BM, Boss JM, Lairmore MD, Durbin JE, Waldman JW, Sedmak DD: Human cytomegalovirus inhibits major histocompatibility complex class II expression by disruption of the Jak/Stat pathway. J Exp Med 1998, 187:675-683.

29. Miller DM, Cebulla CM, Sedmak DD: Human cytomegalovirus inhibition of major histocompatibility complex transcription and interferon signal transduction. Curr Top Microbiol Immunol 2002, 269: $153-170$

30. Boehme KW, Compton T: Innate sensing of viruses by toll-like receptors. I Virol 2004, 78:7867-7873.

31. Child SJ, Hakki M, De Niro KL, Geballe AP: Evasion of cellular antiviral responses by human cytomegalovirus TRSI and IRS I. J Virol 2004, 78: 1 97-205.

32. Browne EP, Shenk T: Human cytomegalovirus UL83-coded pp65 virion protein inhibits antiviral gene expression in infected cells. Proc Natl Acad Sci U S A 2003, 100: I | 439- I I 444.

33. He B, Gross M, Roizman B: The gammal 34.5 protein of herpes simplex virus I has the structural and functional attributes of a protein phosphatase $I$ regulatory subunit and is present in a high molecular weight complex with the enzyme in infected cells. J Biol Chem 1998, 273:20737-20743.

34. Garcia-Sastre A, Egorov A, Matassov D, Brandt S, Levy DE, Durbin JE, Palese P, Muster T: Influenza A virus lacking the NSI gene replicates in interferon-deficient systems. Virology 1998, 252:324-330.

35. Young DF, Didcock L, Goodbourn S, Randall RE: Paramyxoviridae use distinct virus-specific mechanisms to circumvent the interferon response. Virology 2000, 269:383-390.

36. Komatsu T, Takeuchi K, Yokoo J, Tanaka Y, Gotoh B: Sendai virus blocks alpha interferon signaling to signal transducers and activators of transcription. J Virol 2000, 74:2477-2480.

37. He Y, Katze MG: To interfere and to anti-interfere: the interplay between hepatitis $C$ virus and interferon. Viral Immunol 2002, 15:95-119.

38. Basler CF, Wang X, Muhlberger E, Volchkov V, Paragas J, Klenk HD, Garcia-Sastre A, Palese P: The Ebola virus VP35 protein functions as a type I IFN antagonist. Proc Natl Acad Sci U S A 2000, 97:12289-12294 
39. Sainz B Jr, Mossel EC, Peters CJ, Garry RF: Interferon-beta and interferon-gamma synergistically inhibit the replication of severe acute respiratory syndrome-associated coronavirus (SARS-CoV). Virology 2004, 329: I I- 17

40. Larkin J, Jin L, Farmen M, Venable D, Huang Y, Tan SL, Glass Jl: Synergistic antiviral activity of human interferon combinations in the hepatitis C virus replicon system. J Interferon Cytokine Res 2003, 23:247-257.

41. Asper M, Sternsdorf T, Hass M, Drosten C, Rhode A, Schmitz H, Gunther S: Inhibition of different Lassa virus strains by alpha and gamma interferons and comparison with a less pathogenic arenavirus. J Virol 2004, 78:3162-3169.

42. Loewe S: Die quantitativen Probleme der Pharmakologie. Ergebn Physiol 1928, 27:47-187.

43. Berenbaum MC: What is synergy? Pharmacol Rev 1989, 41:93-|4|.

44. Yurochko AD, Kowalik TF, Huong SM, Huang ES: Human cytomegalovirus upregulates NF-kappa B activity by transactivating the NF-kappa B pl05/p50 and p65 promoters. J Virol 1995, 69:539I-5400.

45. Stinski MF, Thomsen DR, Rodriguez JE: Synthesis of human cytomegalovirus-specified RNA and protein in interferontreated cells at early times after infection. J Gen Virol 1982, 60:26I-270.

46. Cheeran MC, Hu S, Gekker G, Lokensgard JR: Decreased cytomegalovirus expression following proinflammatory cytokine treatment of primary human astrocytes. I Immunol 2000 164:926-933.

47. Greaves RF, Mocarski ES: Defective growth correlates with reduced accumulation of a viral DNA replication protein after low-multiplicity infection by a human cytomegalovirus iel mutant. J Virol 1998, 72:366-379.

48. Yamamoto N, Shimokata K, Maeno K, Nishiyama Y: Effect of recombinant human interferon gamma against human cytomegalovirus. Arch Virol 1987, 94:323-329.

49. Gawn JM, Greaves RF: Absence of IEI p72 protein function during low-multiplicity infection by human cytomegalovirus results in a broad block to viral delayed-early gene expression. J Virol 2002, 76:444I-4455.

50. Mocarski ES, Kemble GW, Lyle JM, Greaves RF: A deletion mutant in the human cytomegalovirus gene encoding IEI $(49 \mathrm{Iaa})$ is replication defective due to a failure in autoregulation. Proc Natl Acad Sci U S A 1996, 93: I | 32 I- I 326.

5I. Der SD, Zhou A, Williams BR, Silverman RH: Identification of genes differentially regulated by interferon alpha, beta, or gamma using oligonucleotide arrays. Proc Natl Acad Sci U S A 1998, 95:15623-15628.

52. Huang ES: Human cytomegalovirus. III. Virus-induced DNA polymerase. J Virol I975, 16:298-3 I0.

53. Isomura $H$, Stinski MF: The human cytomegalovirus major immediate-early enhancer determines the efficiency of immediate-early gene transcription and viral replication in permissive cells at low multiplicity of infection. J Virol 2003, 77:3602-36|4.

54. Treco DA: Preparation and analysis of DNA, p.2.0.3-2.2.3. In Current protocols in molecular biology Edited by: Ausubel FM. New York, N.Y., John Wiley \& Sons; 1990.

55. Taylor-Wiedeman J, Sissons JG, Borysiewicz LK, Sinclair JH: Monocytes are a major site of persistence of human cytomegalovirus in peripheral blood mononuclear cells. J Gen Virol I99।, 72 (Pt 9):2059-2064.

56. White EA, Clark CL, Sanchez V, Spector DH: Small internal deletions in the human cytomegalovirus IE2 gene result in nonviable recombinant viruses with differential defects in viral gene expression. J Virol 2004, 78: 1817-1830.

57. Pfaffl MW: A new mathematical model for relative quantification in real-time RT-PCR. Nucleic Acids Res 200I, 29:e45.

58. Soderberg-Naucler C, Streblow DN, Fish KN, Allan-Yorke J, Smith PP, Nelson JA: Reactivation of latent human cytomegalovirus in CDI4(+) monocytes is differentiation dependent. J Virol 200I, 75:7543-7554.
Publish with Bio Med Central and every scientist can read your work free of charge

"BioMed Central will be the most significant development for disseminating the results of biomedical research in our lifetime. "

Sir Paul Nurse, Cancer Research UK

Your research papers will be:

- available free of charge to the entire biomedical community

- peer reviewed and published immediately upon acceptance

- cited in PubMed and archived on PubMed Central

- yours - you keep the copyright
BioMedcentral 